\title{
Zinc Levels and Laboratory Indices in Children with Henoch-Schönlein Purpura
}

\author{
Henoch-Schönlein Purpuralı Çocuklarda Laboratuar Parametreleri ve Çinko \\ Düzeyleri
}

\author{
Binnaz Celik ${ }^{1^{*}}$, Funda Bastug², Burcu Danacı ${ }^{1}$ \\ ${ }^{1}$ Kayseri City Training and Research Hospital, Department of Pediatrics, Kayseri Turkiye \\ ${ }^{2}$ Kayseri City Training and Research Hospital, Department of Pediatric Nephrology, Kayseri Turkiye
}

\begin{abstract}
Objective: We aimed to determine serum zinc concentrations and laboratory parameters of Henoch-Schönlein Purpura (HSP) patients and to evaluate the relationship of these parameters with prognosis of disease.

Materials and Methods: We collected data of patients who diagnosed with HSP seen at our Nephrology department between January 2015 and December 2018. We compared white blood cell count, mean platelet volume, erythrocyte sedimentation rate, C-reactive protein, and serum zinc concentrations in patients with active HSP from those in remission and controls. We also compared this parameters between with or without organ involvement in HSP patients.

Results: Forty-nine male and 35 female patients with HSP were included. We re-evaluated 37 of these patients who were still being followed up during the remission period. The mean age of the active HSP patients was $8.4 \pm 3.7$ years. White blood cell count, C-reactive protein, and erythrocyte sedimentation rate were significantly higher in patients with active HSP compared to remission and control groups. $(p<0.001)$. No significant difference was found in plasma zinc concentration between active HSP, remission, and control groups. In addition, zinc and other laboratory parameters were not significantly different between HSP patients with or without organ involvement.

Conclusions: Our findings suggest that zinc supplementation to patients with active Henoch-Schönlein purpura will not be meaningful in terms of the prognosis of the disease. However, more studies are needed to say that zinc supplements are not necessary in Henoch-Schönlein pupura.

Key Words: Child, Henoch-Schönlein Purpura, laboratory parameters, zinc
\end{abstract}

\section{Objective}

Henoch-Schönlein purpura (HSP) is a leukocytoclastic vasculitis and affects small vessels. It is characterized by purpura and the most common vasculitis in childhood. Arthralgia or arthritis, gastrointestinal, and renal involvement are other clinical manifestations (1). It occurs in

\begin{abstract}
Özet
Amaç: Çalışmamızda Henoch-Schönlein purpuralı hastaların laboratuar parametreleri ve çinko konsantrasyonları, ayn zamanda bu parametrelerin hastalı̆̆ı prognozu ile ilişkisini değerlendirmek amaçlanmıştır.

Gereç Ve Yöntem: Bu prospektif vaka-kontrol çalışması için Aralık 2015-Ocak 2018 tarihleri arasında Çocuk Nefroloji departmanımıza başvuran Henoch-Schönlein purpura tanılı hastaların bilgilerini kaydettik. Aktif Henoch-Schönlein purpura tanıli, remisyon ve kontrol grubu hastalarının beyaz kan hücresi sayis1, ortalama trombosit hacmi, C-reaktif protein, eritrosit sedimentasyon hızı ve serum çinko konsantrasyonlarını değerlendirmeye aldık. Bu parametreleri organ tutulumu olan ve olmayan hastalar arasında da karşılaştırdık.
\end{abstract}

Bulgular: Aktif Henoch-Schönlein purpura tanılı hastaların 49'u erkek, 35'i kızdi. Bu hastaların takibe devam eden 37'sini de remisyon döneminde yeniden değerlendirdik. Hasta grubunun ortalama yaşı $8.4 \pm 3.7$ yaş idi. Beyaz kan hücresi sayıs1, C-reaktif protein ve eritrosit sedimentasyon hizı aktif hastalık grubunda kontrol ve remisyon grubuna göre anlaml derecede daha yüksekti $(\mathrm{p}<0.001)$. Hasta, kontrol ve remisyon grubu arasında çinko konsantrasyonlarında anlamlı fark bulunamadi. Bununla birlikte aktif hastalık grubunda organ tutulumu olan ve olmayan hastalar karşılaştırıldığında da çinko ve diğer laboratuar parametreleri açısından anlamlı fark bulunamadi.

Sonuç: Bulgularımız aktif Henoch-Schönlein purpuralı hastalara çinko desteği vermenin hastalığın prognozu açısından anlaml olmayacağını düşündürmektedir. Ancak çinko destek tedavisinin gerekli olup olmadığını belirlemek için daha fazla çalışma gereklidir.

Anahtar Kelimeler: Çocuk, Henoch-Schönlein Purpura, laboratuat parametreleri, cinko

10-20 of 100,000 children annually (2). The etiology of HSP remains unknown, although infections (mainly upper respiratory tract infections), drugs, food, insect bites, and vaccinations may trigger HSP. Nonetheless, HSP may be regarded as an infection-related immunemediated disease, although the infectious agent is 
Çelik ve ark. / Zinc levels in Henoch-Schönlein purpura

usually undetec table (3). HSP vasculitis is characterized by the accumulation of immune complexes and complement components containing immunoglobulin A $(\operatorname{IgA})$ in the skin, intestines, joints, and kidney mesangium (4).

The short- and long-term prognoses of HSP are mostly excellent. Its first episode typically resolves within one month; however, severe systemic involvement and long-term complications may rarely occur (5). Renal involvement is long-term complication of HSP. It is presenting as nephritic and nephrotic syndrome or renal failure (6). The levels of interleukin (IL)-2 and the proportion of cluster of differentiation (CD) $3+$ and CD $4+$ cells are reduced in HSP patients. Consequently, the number of B-cells may be significantly increased, and immunoglobulin levels may also be increased in HSP patients (7). Zinc is a trace element. It plays an important role in growth and development, mucosal barrier functions, enzymatic activity, and innate and adaptive immunity (8). Furthermore, zinc inhibits monocyte adhesion to endothelial cells and is important in the formation of interleukin-(IL-6), interleukin-1 beta (IL-1 $\beta$ ) and tumor necrosis factor $\alpha(\mathrm{TNF} \alpha)$ (9). Zinc deficiency results to thymic atrophy caused by a steep decline in the number of T-cells, and immature and premature B-cell lymphocytes (10). Plasma zinc concentrations decrease rapidly during the acute phases of stress, infection, and trauma. As a result, zinc enters intracellular compartments where it is utilized for protein synthesis, prevention of microbial invasion, and neutralization of free radicals (11). We aimed to evaluate the zinc status in patients with active HSP and to determine its relationship with organ involvement. We also aimed to compare white blood cell count (WBC), mean platelet volume (MPV), C-reactive protein (CRP), and erythrocyte sedimentation rate (ESR), between active HSP, remission, and control groups.

\section{Materyal and Methods}

This study is a prospective case-control study. We collected the medical data of patients diagnosed with HSP seen at our Nephrology department between January 2015 and December 2018. The active disease was defined as the period in which the patient showed active clinical features, including skin purpura, arthralgia or arthritis, hematuria or proteinuria, and colicky abdominal pain. This group included 105 patients. Five patients with chronic comorbid conditions were excluded from the study. Eight patients who received systemic steroid treatment before application of our department were excluded from the study. The parents of eight patients refused to participate in the study, and were likewise excluded. The clinical and laboratory findings of the 84 remaining active HSP patients were evaluated. The diagnosis of HSP was made according to the diagnostic criteria developed by the European League against Rheumatism/Pediatric Rheumatology European Society (EULAR/PRES) (12). All cases developed palpable purpura and one or more of the following criteria were present: arthralgia or arthritis, gastrointestinal system (GIS) involvement, renal involvement, and biopsy of affected tissues showing predominant $\operatorname{IgA}$ deposition. We defined joint involvement as arthralgia or arthritis. Colicky abdominal pain, vomiting, and hematochezia or melena was identified as GIS involvement. Hematuria (more than five erythrocyte per high-power microscopic field in a centrifuged urine specimen) or proteinuria (spot urine protein/creatinine ratio greater than 0.5 in children less than 2 years of age, and greater than 0.2 in children at least 2 years of age) was also defined as renal involvement. Based on both the clinical and laboratory findings, an additional 37 patients with HSP in complete remission for approximately 1-2 months were recruited in the remission group. A clinical scoring system was used to seperate the active or remission phases (13). The control group consisted of 30 healthy children undergoing routine physical examination at our general pediatric policlinics. Informed consent form was obtained from the parents of all children.Serum zinc concentration, extracted at the time of diagnosis, was the primary outcome variable. Other laboratory data included WBC, CRP, ESR, MPV, urinalysis, and fecal occult blood test results. The demographic data and presenting clinical symptoms of the subjects were also recorded. All the blood samples of the patients were taken by an experienced healthcare provider in the morning on a full stomach. During analysis, environmental contamination was avoided following the International Zinc Nutrition Advisory Group (IZiNCG) guidelines. Serum zinc conventrations were measured using an atomic absorption spectrophotometer (AAS) method with flame spectrophotometer. Approval was obtained from the local ethics committee for this study (Erciyes University Ethical Committee No: 2017/296). 
Table 1: The main clinical features of HSP patients

\begin{tabular}{lcccc}
\hline & \multicolumn{2}{c}{ Male } & Gender & Total \\
$(n=49)$ & & $\begin{array}{c}\text { Female } \\
(n=35)\end{array}$ & p-value \\
\cline { 2 - 3 } & & & & \\
\cline { 2 - 3 } & & & & \\
Joint involvement & $10(20.4)$ & $7(20.0)$ & $17(20.2)$ & 0.999 \\
$\quad$ No & $39(79.6)$ & $28(80.0)$ & $67(79.8)$ & \\
$\quad$ Yes & $35(71.4)$ & $25(71.4)$ & $60(71.4)$ & 0.999 \\
$\quad$ GIS involvement & $14(28.6)$ & $10(28.6)$ & $24(28.6)$ & \\
$\quad$ No & $44(89.8)$ & $33(94.3)$ & $77(91.7)$ & 0.694 \\
$\quad$ Yes & $5(10.2)$ & $2(5.7)$ & & \\
Renal involvement & No & & & \\
$\quad$ Yes & & & & \\
\hline
\end{tabular}

HSP; Henoch-Schönlein purpura; GIS, gastrointestinal system

Table 2: The main laboratory features of patients with HSP, control, and remission groups

\begin{tabular}{|c|c|c|c|c|c|}
\hline \multirow[b]{2}{*}{ Variables } & \multicolumn{3}{|c|}{ Groups } & \multirow{2}{*}{$\begin{array}{c}\text { Total } \\
(\mathrm{n}=151)\end{array}$} & \multirow[b]{2}{*}{$\mathrm{p}$-value } \\
\hline & $\begin{array}{r}\text { Controls } \\
(n=30)\end{array}$ & $\begin{array}{c}\text { Active HSP } \\
(n=84)\end{array}$ & $\begin{array}{c}\text { Remission } \\
(n=37)\end{array}$ & & \\
\hline WBC & $7.1(6.1-7.7)^{\mathrm{b}}$ & $9.3(7.6-10.9)^{a}$ & $7.7(6.5-8.9)^{\mathrm{b}}$ & $7.9(6.8-10.0)$ & $<0.001$ \\
\hline CRP & $3.2(3.2-3.2)^{\mathrm{b}}$ & $9.0(3.2-16.0)^{\mathrm{a}}$ & $3.3(3.2-3.4)^{\mathrm{b}}$ & $3.4(3.2-10.7)$ & $<0.001$ \\
\hline ESR & $2.0(2.0-6.3)^{\mathrm{b}}$ & $11.0(6.3-19.8)^{a}$ & $5.0(2.0-11.5)^{\mathrm{c}}$ & $8.0(3.0-15.0)$ & $<0.001$ \\
\hline Zinc & $74.83 \pm 9.45$ & $76.39 \pm 20.27$ & $74.18 \pm 17.65$ & $75.54 \pm 17.90$ & 0.801 \\
\hline MPV & $8.82 \pm 0.60$ & $9.10 \pm 0.88$ & $9.09 \pm 0.96$ & $9.04 \pm 0.86$ & 0.289 \\
\hline
\end{tabular}

HSP, Henoch-Schönlein purpura; WBC, white blood cell count; CRP, C-reactive protein; ERS, erythrocyte sedimentation rate; MPV, mean platelet volume

Statistical Analysis: Statistical analyses were performed using SPSS 22.0 software package (IBM, Armonk, NY). Distribution of the data was evaluated using the Shapiro-Wilk test. Variance of homogeneity was assessed using the Levene's test. The Mann-Whitney U test for non-parametric data or independent two samples t-tests for normally distributed data were used to compare quantitative variables between the two groups. The Kruskal Wallis test and One-Way analysis of Variance were used to compare quantitative variables between more than two groups. The Dunn-Bonferroni test was used for multiple comparisons. Categorical data compared to pearson $\chi^{2}$ and Fisher's exact $\chi^{2}$ analyses. The relationship between quantitative data was evaluated using Spearman correlation analysis. The statistical level of significance for all tests was 0.05 .

\section{Results}

We reviewed 49 boys (58.3\%) and $35(41.7 \%)$ girls active HSP patients. The boys to girls ratio was 1.4. The mean age of HSP active patients were 8.4 \pm 3.7 years. The remission group consisted of 24 boys $(64.9 \%)$ and 13 girls $(35.1 \%)$, and the mean age was $9.4 \pm 4$ years. The control group consisted of 12 boys (40\%) and 18 girls (60\%) with a mean age of $8.3 \pm 3.8$ years. No significant differences were found in the age and sex between active HSP, remission and control groups ( $p>$ $0.05)$. There were also no significant differences in age and sex distributions between those with and without organ involvement $(\mathrm{p}>0.05)$. (Table1) Laboratory findings of patients in the active HSP, remission, and control groups are presented in Table 2. WBC, CRP, and ESR were significantly higher in patients with active HSP than in the remission or control groups $(p<0.001)$. However, no statistically significant differences were found 
in the zinc and MPV levels between the HSP, control, and remission groups $(\mathrm{p}=0.80$ and $\mathrm{p}=$ 0.28 , respectively). There were no significant differences in WBC, MPV, CRP, ESR, and zinc levels between patients with and without organ involvement ( $p>0.05)$.

\section{Discussion}

In this study, we examined the WBC, CRP, ESR, $\mathrm{MPV}$, and zinc levels in the active HSP, remission, and control groups. We also compared these variables between HSP patients with and without organ involvement. Renal involvement is the most serious complication of HSP, which also determines the prognosis of the disease. Considering the effect of zinc on immunity, our study aimed to determine the degree of zinc deficiency in patients with active HSP and to determine whether zinc prophylaxis is required for the prevention of complications. However, no statistically significant difference was found in serum zinc levels between the active HSP, remission, and control groups. No significant relationship was also found between disease activity and zinc levels. HSP is commonly diagnosed in children under 10 years old, most often between the ages of 2-10 (12). In the present study, the mean age $(8.4 \pm 3.7$ years $)$ of HSP patients reflects this age distribution. In some studies, boys were more affected than girls [13], while in others, girls were more affected (14). The boys to girls ratio was 1.4 in our patient group. In the remission group, the ratio of boys to girls was 1.8. Statistically significant differences were not found between the active and remission groups in terms of sex and age distribution.Abdominal pain, GI bleeding, and vomiting are the most common GI symptoms of HSP patients, with a reported incidence of $34-75 \%$ (15). It was suggested that a low MPV level was related with GI bleeding (16). Conversely, in other studies, high MPV values were associated with GI bleeding (17). GIS involvement in our patients was $28.6 \%$, and we found no relationship between GIS involvement and MPV levels. Potentially, the most serious outcomes of HSP are associated with renal involvement, and renal findings usually occur within three months after the onset of the disease. Of those with HSP, 20-55\% may develop renal manifestations (18). In two studies evaluating the organ involvement of patients with HSP, renal involvement was found in $5.6 \%$ of patients at the time of admission $(12,19)$. The rate observed in our patients was $8.3 \%$ because we also included renal involvement at admission. Neutrophil and monocyte counts have been reported to be useful in predicting multisystemic involvement, with a positive correlation between CRP and disease severity (20). In another study; WBC, lymphocyte, neutrophil, and platelet counts, platelet to lymphocyte ratio (PLR), neutrophil to lymphocyte ratio (NLR), hemoglobin, MPV, albumin, and CRP levels were all significantly associated with GI involvement and bleeding in children with HSP (21). We found no significant differences in WBC, CRP, ESR, MPV and zinc concentrations between patients with and without joint, GIS or kidney involvement. Serum zinc levels have not been evaluated previously in children with HSP or other vasculitis. No significant differences were found in serum zinc levels between the active HSP, control, and remission groups in our study. We also found no differences in zinc levels between HSP active patients with and without organ involvement. This may be because analyzed zinc levels were extracted at the time of admission. Serum zinc levels in JRA patients were not significantly different in the control group and were not related in disease activity (22). Zinc levels in adult patients with systemic lupus erythematosus and rheumatoid arthritis were lower than that in the control groups $(23,24)$. Plasma zinc concentration decreases in cases of infection, inflammation, stress, or trauma. However, in catabolic conditions such as hunger, the level of zinc may increase owing to the release of zinc into the circulation (25). As a result, zinc levels are affected by many factors. Therefore, in future studies, zinc levels in HSP patients should be taken right after the onset of the disease, taking starvation levels into account. Zinc levels are also higher in children than in adults, especially during periods of rapid growth. Rheumatoid arthritis and systemic lupus erythematosus are chronic systemic diseases, while HSP is usually an acute and selflimited disease; therefore, zinc levels may be normal during active disease. The low number of patients is one of the limitations of our study. Another limitation of our study is the evaluation of the organ involvement and laboratory findings of the patients only at the time of admission. In addition, only the organs involved was evaluated, and not the severity of these conditions. Future studies that determine serum zinc levels according to the severity of organ involvement may be important, because treatment with zinc may prevent the progression of inflammation and the development of serious complications. In conclusion, our results revealed that CRP, ESR, and WBC levels were significantly higher in active HSP patients than in 
the remission and control groups. However, zinc levels were not significantly different. Our study provides valuable information to healthcare providers to avoid unnecessary zinc supplementation to patients with HSP as it may not contribute to improving clinical outcomes.

Conflict of Interests: The authors have no conflict of interest.

\section{References}

1. Kawasaki Y, Suzuki H. Henoch-Schonlein Nephritis. In: Geary D, Shaefer F, editors. Comprehensive pediatric nephrology. 1 est ed. Philadelphia: Mosby Elsevier 2008; 34351.

2. He X, Yu C, Zhao P, Ding Y, Liang X, Zhao $Y$, et al. The genetics of HenochSchonlein purpura: a systemic review of meta-analyses. Rheumatol Int 2013;33(6):1387-1395.

3. López-Mejías R, Castañeda S, Genre F, Remuzgo-Martínez S, Carmona FD, Llorca $\mathrm{J}$, et al. Genetics of immunoglobulin-A vasculitis (HenochSchönlein purpura): an updated review. Autoimmun Rev 2018;17:301- 305.

4. Chen JY, Mao JH. Henoch-Schonlein purpura nephritis in children: incidence, pathogenesis and management. World J Pediatr 2015;11(1):29-34.

5. Rhim JW, Lee YT, Kang HM, Suh JS, Lee KY. Changes in clinical features in HenochSchönlein purpura during three decades: an observational study at a single hospital in Korea. Clin Rheumatol 2019;38(10):28112818.

6. Gökçe Ş, Kurugöl Z, Koturoğlu G, Aslan A. Predictive Role of Laboratory Markers and Clinical Features For Recurrent Henoch-Schönlein Purpura in Childhood: A Study from Turkey. Mod Rheumatol 2020;30(6):1047-1052..

7. Pan YX, Ye Q, Shao WX, Shang SQ, Mao $\mathrm{JH}$, Zhang T, et al. Relationship between immune parameters and organ involvement in children with Henoch-Schonlein purpura. PLoS One 2014;9(12):e115261.

8. Kaur K,Goupta R, Saraf SA, Saraf SK. Zinc: the metal of life. Compr Rev Food Sci Food Saf 2014;13(4):358-376.

9. Haase $H$, Rink L. Zinc signals and immune function. BioFactors 2014;40(1):27-40.

10. Gammoh NZ, Rink L. Zinc in Infection and Inflammation. Nutrients 2017;9(6):624.
11. Fraker PJ, King LE. Reprogramming of the immune system during zinc deficiency. Annu Rev Nutr 2004;24:277-298.

12. Ozen S, Pistorio A, Lusan SM, Bakkaloglu A, Herlin T, Brik R, et al. EULAR/PRINTO/PRES criteria for Henoch-Schönlein purpura, childhood polyarteritis nodosa, childhood Wegener granulamatosis and childhood Takayasu arteritis: Ankara 2008. Part II : final classification criteria. Ann Rheum Dis 2010;69(5):798-806.

13. Tabel Y, Inanc FC, Dogan DG, Elmas A. Clinical features of children with HenochSchonlein purpura risk factors associated with renal involvement. Iran J Kidney Dis 2012;6(4):269-274.

14. Garcia-Porrua C, Calvino MC, Llorca J, Couselo JM, Gonzalez-Gay MA. HenochSchonlein purpura in children and adults: clinical differences in a defined population. Semin Arthritis Rheum 2002;32(3):149-156.

15. Hwang HH, Lim IS, Choi BS, Yi DY. Analysis of seasonal tendencies in pediatric Henoch-Schonlein purpura and comparison with outbreak of infectious diseases. Medicine (Baltimore) 2018;97(36):e12217.

16. Trapani S, Michelli A, Grisolia F, Resti M, Chiappini E, Falcini F, et al. HenochSchonlein purpura in childhood: epidemiological and clinical analysis of 150 cases over a 5 -year period and review of literature. Semin Arthritis Rheum 2005;35(3):143-153.

17. Makay B, Türkyilmaz Z, Duman M, Unsal E. Mean platelet volume in HenochSchönlein purpura: relationship to gastrointestinal bleeding. Clin Rheumatol 2009;28(10):1225-1228.

18. Mir S, Yavascan O, Mutlubas F, Yeniay B, Sonmez F. Clinical outcome in children with Henoch-Schonlein nephritis. Pediatr Nephrol. 2007;22(1):64-70.

19. Karadag SG, Tanatar A, Sonmez HE, Çakmak F, Kiyak A, Yavuz S, et al. The clinical spectrum of Henoch-Schönlein purpura in children: a single-center study. Clin Rheumatol 2019;38(6):1707-1714.

20. Teng $X$, Wang $Y$, Lin $N$, sun $M$, Wu J. Evaluation of serum procalcitonin and Creactive protein levels as biomarkers of Henoch-Schönlein purpura in pediatric patients. Clin Rheumatol 2016;35(3):667671.

21. Özdemir ZC, Çetin N, Kar YD, Öcal HO, Bilgin M, Bor Ö. Hemotological Indices for 
Çelik ve ark. / Zinc levels in Henoch-Schönlein purpura

Predicting Internal Organ Involvement in Henoch-Schönlein Purpura (IgA vasculitis). J Pediatr Hematol Oncol 2020;42(1):e46e49.

22. Tuncer S, Kamanli A, Akçil E, Kavas GO, Seckin B,Atay MB. Trace element and magnesium levels and superoxide dismutase activity in rheumatoid arthritis. Biol Trace Elem Res 1999;68(2):137-142.

23. Soylak M,Kirnap M. Serum copper and zinc concentrations of patients with rheumatoid arthritis from Kayseri-Turkey. Fresen Environ Bull 2001;10(4); 409-410.
24. Yilmaz A, Sari RA, Gundogdu M, Kose N, Dag E. Trace elements and some extracellular antioxidant proteins levels in serum of patients with systemic lupus erythematosus. Clin Rheumatol 2005;24(4):331-335.

25. Moran VH, Stammers AL, Medina MW, Patel S, Dykes F, Souverein OW, et al. The relationship between zinc intake and serum/plasma zinc concentration in children: a systematic review and doseresponse meta-analysis. Nutrients 2012;4(8):841-858. 